\title{
Life cycle of the temporary fish parasite, Gnathia africana (Crustacea: Isopoda: Gnathiidae)
}

\author{
Nico J. Smit ${ }^{1,3}$, Linda Basson ${ }^{2}$ and Jo G. Van $\mathbf{A s}^{2}$ \\ ${ }^{1}$ School of Life Sciences, Kingston University, Penrhyn Road, Kingston upon Thames, Surrey, KT1 2EE, UK; \\ ${ }^{2}$ Department of Zoology and Entomology, University of the Free State, P.O. Box 339, Bloemfontein, 9300, South Africa; \\ ${ }^{3}$ Present address: Department of Zoology, University of Cape Town, Private Bag, Rondebosch, 7701, South Africa
}

Key words: Isopoda, Gnathiidae, Gnathia africana, life cycle, fish parasite

\begin{abstract}
Laboratory work was conducted to elucidate the life cycle of the South African gnathiid isopod, Gnathia africana Barnard, 1914. The natural fish hosts of this temporary parasite, the super klipfish Clinus superciliosus (Linnaeus, 1758), were exposed to gnathiid larvae in the laboratory. It was found that $G$. africana has three larval stages, consisting of three unfed (zuphea) and three fed (praniza) stages. First-, second- and third-stage zuphea larvae took an average of $2 \mathrm{~h} 18 \mathrm{~min}, 2 \mathrm{~h} 43 \mathrm{~min}$ and $10 \mathrm{~h} 8 \mathrm{~min}$ respectively to complete their feeding and the first- and second-stage praniza moulted at 8 and 10 days respectively into the next zuphea stage. Three to six days after its last blood meal, the sex of the third and final praniza stage could be determined by the presence of either a testis or two ovaries in the dorsal pereon. Male larvae moulted into adult males between 8 and 10 days post feeding. Female larvae moulted at approximately 17 days into adult females. Fertilisation of the eggs by the male took place within 24 hours of completion of the female moult. The development of the embryos and subsequent release of the young larvae between 15 and 23 days post fertilisation completed the cycle. This entire cycle took approximately 62 days in water temperatures of $20-25^{\circ} \mathrm{C}$.
\end{abstract}

The life cycle and ecology of members of the family Gnathiidae have intrigued scientists for more than two centuries. Even now the information available on these aspects of gnathiid biology is scanty. To the authors' knowledge the life cycle of only the following six of the more than 170 described gnathiid species has been researched in any detail: Gnathia maxillaris (Montagu, 1804) by Smith (1904) and Mouchet (1928); G. piscivora Paperna et Por, 1977 by Paperna and Por (1977); Paragnathia formica (Hesse, 1864) by Monod (1926), Mouchet (1928), Stoll (1962, 1963), Amanieu (1963) and Upton (1987a, b); Caecognathia calva (Vanhöffen, 1914) by Wägele $(1987,1988)$; C. abyssorum (Sars, 1872) by Klitgaard (1991, 1997); and Elaphognathia cornigera (Nunomura, 1992) by Tanaka and Aoki (1998, 1999, 2000).

Gnathia africana Barnard, 1914 was the first gnathiid species to be described from southern Africa (Barnard 1914a, b). This species is very common along the South African west and south coasts where the parasitic larvae feed on the blood and lymph fluid of residential intertidal fishes (Smit and Davies 1999, Smit et al. 1999). The resting larvae and adult stages are found in a variety of sponges, tunicates and tubes of serpulid worms (Barnard 1914b, Smit et al. 1999). The abundance of these gnathiids in the intertidal zone and the availability of their fish hosts make them perfect research specimens, especially for life-cycle experiments. It has recently been shown by Davies and Smit (2001) that G. africana acts as a vector for the blood parasite Haemogregarina bigemina Laveran et Mesnil, 1901. This fact underlines the importance of further research into the life cycle and history of gnathiids in general. This paper reports on the life cycle of $G$. africana constructed from field and laboratory work.

\section{MATERIALS AND METHODS}

Material used in the laboratory experiments during the present study was collected during October 1998 at Jeffreys Bay. Fish were collected and examined for parasites as described by Smit and Davies (1999), Smit et al. (1999) and Davies and Smit (2001). Gnathiids were also collected from sponges (see Smit et al. 1999). Live final-stage larvae were kept in 50-ml plastic screw-top containers of seawater and transported back to the Department of Zoology and Entomology, University of the Free State, where a marine aquarium was set up to maintain fish for use as hosts in feeding experiments with parasitic larval stages of Gnathia africana. The fish host used for these experiments was the super klipfish Clinus superciliosus (Linnaeus, 1758). This widespread intertidal fish species was found to be a common intertidal host for G. africana larvae (Smit and Davies 1999). Initially, artificial sponges, as used by Wägele (1988) were built to serve as a resting place for adults and resting larvae, but it was found that the animals survived perfectly well in the $50-\mathrm{ml}$ screw-top containers of seawater alone. It was, however, important to exchange the water regularly (once every third day) and to clean each gnathiid with a small brush in order to remove debris from the body, especially from the pleopods and dorsal pereon. All animals were kept in seawater 
at temperatures between 20 and $25^{\circ} \mathrm{C}$. Gnathiids were examined daily under a dissection microscope to monitor their condition.

During feeding experiments a single host fish was placed in a 25-1 aerated aquarium. A single zuphea larva from the laboratory-reared culture was placed with the fish by means of a plastic pipette. The feeding period of 20 zuphea (unfed) larvae of each stage (Z1-Z3) was measured from the time of attachment on the host to detachment from the host to the nearest five minutes. The positions of attachment of each larva were also recorded. Twenty larvae of each stage were measured to the nearest $0.1 \mathrm{~mm}$ in order to determine the increase in length between different stages. All measurements are presented as range (mean \pm standard deviation). The time of digestion of 20 praniza (fed) larvae of each stage (P1-P2) was measured from the day of detachment to the day on which they moulted into the next stage.

\section{RESULTS}

A total of 33 final-stage larvae were collected from their fish hosts and 14 from sponges at Jeffreys Bay. Of the 33 larvae collected from fish, 16 moulted into males and 17 into females. Of these females, 11 survived the whole term of the experimental period (from detachment from fish host to release of stage 1 zuphea larvae). All 14 final-stage larvae collected from sponges moulted into males.

To obtain the feeding and moulting data for 60 larvae, 73 larvae were used. The reason for this was that the fish killed 13 of the larvae by removing them from their bodies (in most cases from the caudal fin) with their teeth. Of these larvae, the fish ate six, the other seven were spat out.

Zuphea 1 (Z1). The larvae (zuphea 1) released by females started to feed immediately on the fish hosts in the laboratory. The cohorts of Z1 larvae from differentsized females were almost uniform in size $(1.0-1.1 \mathrm{~mm})$. During feeding experiments, Z1 larvae attached to the host fish for between 1 hour 15 minutes and 4 hours 10 minutes (mean $2 \mathrm{~h} 18 \mathrm{~min}$ ). On comparing the length of the feeding period of $\mathrm{Z1}$ larvae attached to different areas on the fish host, a correlation was evident between the attachment site on the host and the length of the feeding period. Larvae attached to the body of the host were able to finish their feeding much faster than those attached to the fins. Upon completion of feeding the larvae left the fish host as praniza 1 larvae.

Praniza 1 (P1). The detached P1 larvae ranged in length from 1.4 to $1.6 \mathrm{~mm}$ (mean $1.5 \pm 0.06 \mathrm{~mm}$ ). This means that the first feeding period led to an average increase of $0.5 \mathrm{~mm}$ in length. The P1 larvae started to moult into zuphea 2 larvae at seven to nine days (average 8 days) post feeding. The moulting process was a characteristic isopod moult, consisting of a posterior moult followed by an anterior moult (Fig. 1). The moulting process took between 40 and 90 minutes to complete. The newly moulted larvae were able to use their limbs after 15 minutes and could swim 30 minutes after completion of the moult.

Zuphea 2 (Z2). On completion of the moult, the remainder of the blood/lymph meal was still visible in the anterior hindgut of the Z2 larvae. The length of the Z2 larvae was $1.5-1.8 \mathrm{~mm}$ (mean $1.7 \pm 0.09 \mathrm{~mm}$ ), thus resulting in an increase of $0.2 \mathrm{~mm}$ in length. The $\mathrm{Z} 2$ larvae were again ready to feed two to three days postmoulting. At that stage none of the previous meal was visible in the anterior hindgut. The feeding period of the Z2 larvae ranged from 1 hour 15 minutes to 4 hours (mean $2 \mathrm{~h} 43 \mathrm{~min}$ ), not much longer than that of the Z1 larvae. As in the case of the Z1 larvae, Z2 larvae that attached to the body of the host fish were able to complete their feeding more rapidly than those attached to the fins of the host. The results of the second feeding phase were praniza 2 larvae.

Praniza 2 (P2). The P2 larvae were 2.2-2.6 mm long (mean $2.4 \pm 0.1 \mathrm{~mm}$ ). The average increase in length of $0.7 \mathrm{~mm}$ produced by the second feeding period was almost one and a half times more than that of the first feeding stage. The size range of the larvae also increased. The P2 larvae spent between 7 and 16 days (mean $10 \pm 2.5$ days) in a resting and digesting phase before they moulted into the next larval stage. Moulting again followed the same pattern as for the P1 larvae, taking 40-100 $\mathrm{min}$ to complete. The resulting larvae (zuphea 3) were the final feeding stages.

Zuphea 3 (Z3). The Z3 larvae ranged in size from 2.3 to $2.8 \mathrm{~mm}$ (mean $2.6 \pm 0.16 \mathrm{~mm}$ ). As in the case of the Z2 larvae, the Z3 larvae gained an average of 0.2 $\mathrm{mm}$ in length through moulting. Five days after moulting, the last of the blood meal was digested and the larvae were ready to feed again. The feeding period of the Z3 larvae (mean $10 \mathrm{~h} 8 \mathrm{~min}$ ) was, on average, almost five times as long as those of the $\mathrm{Z} 1$ and $\mathrm{Z} 2$ larvae. In some cases a feeding period of more than 20 hours was recorded. The feeding process resulted in an average increase of $1.2 \mathrm{~mm}$ in length. The now P3 larvae varied in length from 3.1 to $4.5 \mathrm{~mm}$ (mean $3.8 \pm$ $0.35 \mathrm{~mm}$ ). The P3 larvae (Fig. 2) were the final larval stages and could be separated into male and female larvae.

Male. In the P3 larvae that were going to moult into males, the testes could be seen situated in the dorsal pereon between three to five days after feeding (Fig. 3). The male larvae of $G$. africana were also characterised by the elongation of the first pereonite forming a dilated region behind the cephalosome (Fig. 13) as described by Monod (1926) for Paragnathia formica. After 8 to 10 days, the male larva underwent the final moult into an adult male. In a single case the testis was observed 10 days post feeding in the male larva and the moulting only commenced after 19 days. The moulting process of G. africana P3 larvae also consisted of a posterior moult followed by an anterior moult, as described for other 


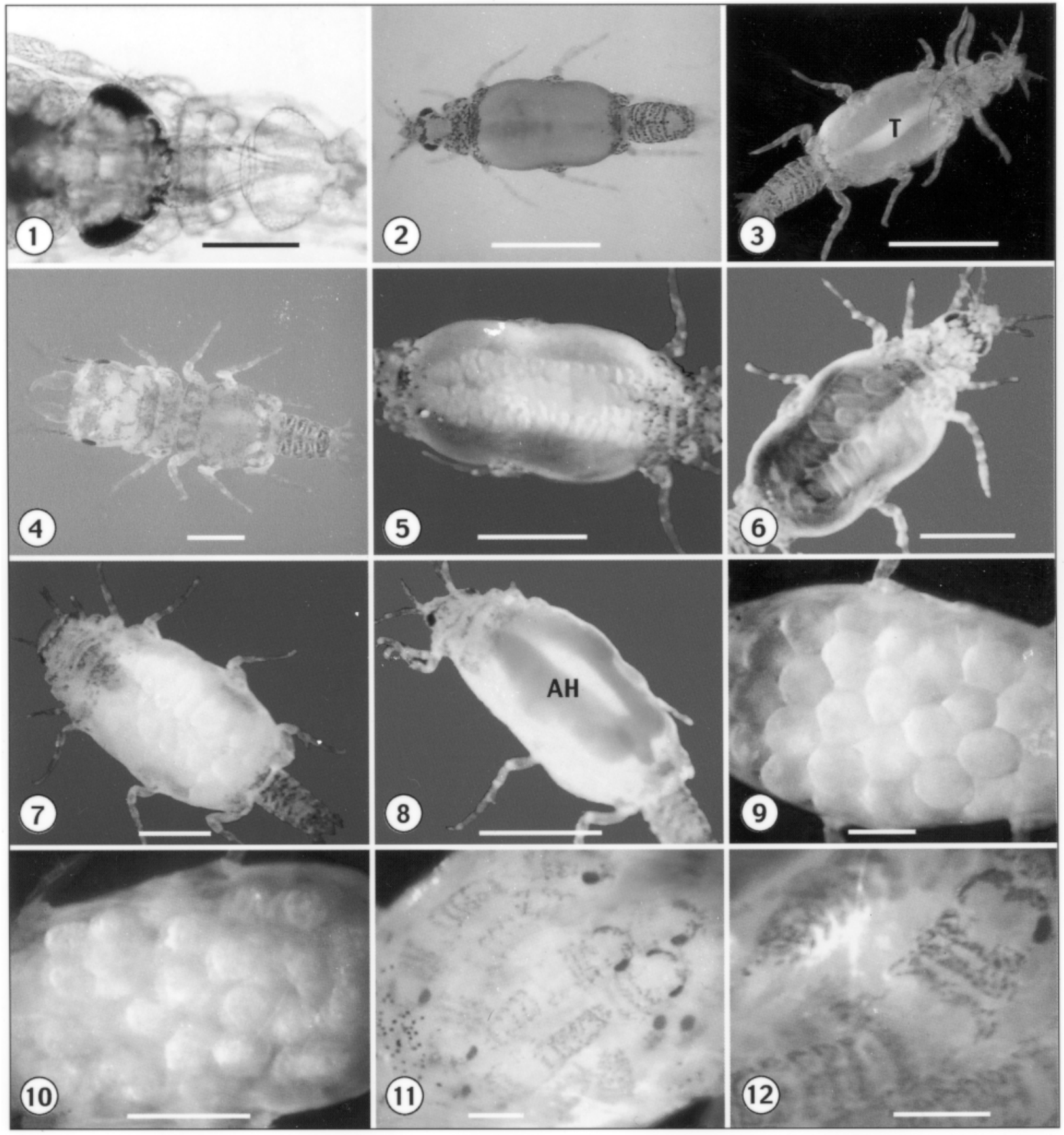

Figs. 1-12. Light micrographs of the different developmental stages of Gnathia africana Barnard, 1914. Fig. 1. Praniza 1 during the anterior moult. Fig. 2. Dorsal view of a fully fed praniza 3. Fig. 3. Dorsal view of a male praniza 3 with testis (T). Fig. 4. Adult male with characteristic pigmentation. Fig. 5. Female larva with eggs filling half of dorsal pereon. Fig. 6. Female larva with eggs filling complete dorsal pereon. Fig. 7. Dorsal view of recently moulted adult female. Fig. 8. Anterior hindgut (AH) of female with remaining blood meal dorsally visible. Fig. 9. Round fertilized eggs in the ventral marsupium of an adult female. Fig. 10. Eggs in marsupium undergoing cell division. Fig. 11. Eyes, cephalosome, pereonites and pleonites of embryos visible. Fig. 12. First-stage larva ready to leave marsupium. Scale bars: Figs. 1, 11, $12=100 \mu \mathrm{m}$; Figs. $2-10=1 \mathrm{~mm}$.

gnathiid species. The posterior moult took about one to two hours to complete. During this process formation of each adult pleonite could be seen. Upon completion of the posterior moult, the new adult's pereopods were not used for at least eight hours. At that stage, the adult posterior end could easily be distinguished from the larval anterior end (Fig. 14). About 14 hours after the posterior moult, the anterior moult commenced (Fig. 15). This was a much more complex moult and took up to four hours to complete. The newly formed cephalosome is soft and without the distinct G. africana pigmentation. This is a very vulnerable stage in the life 

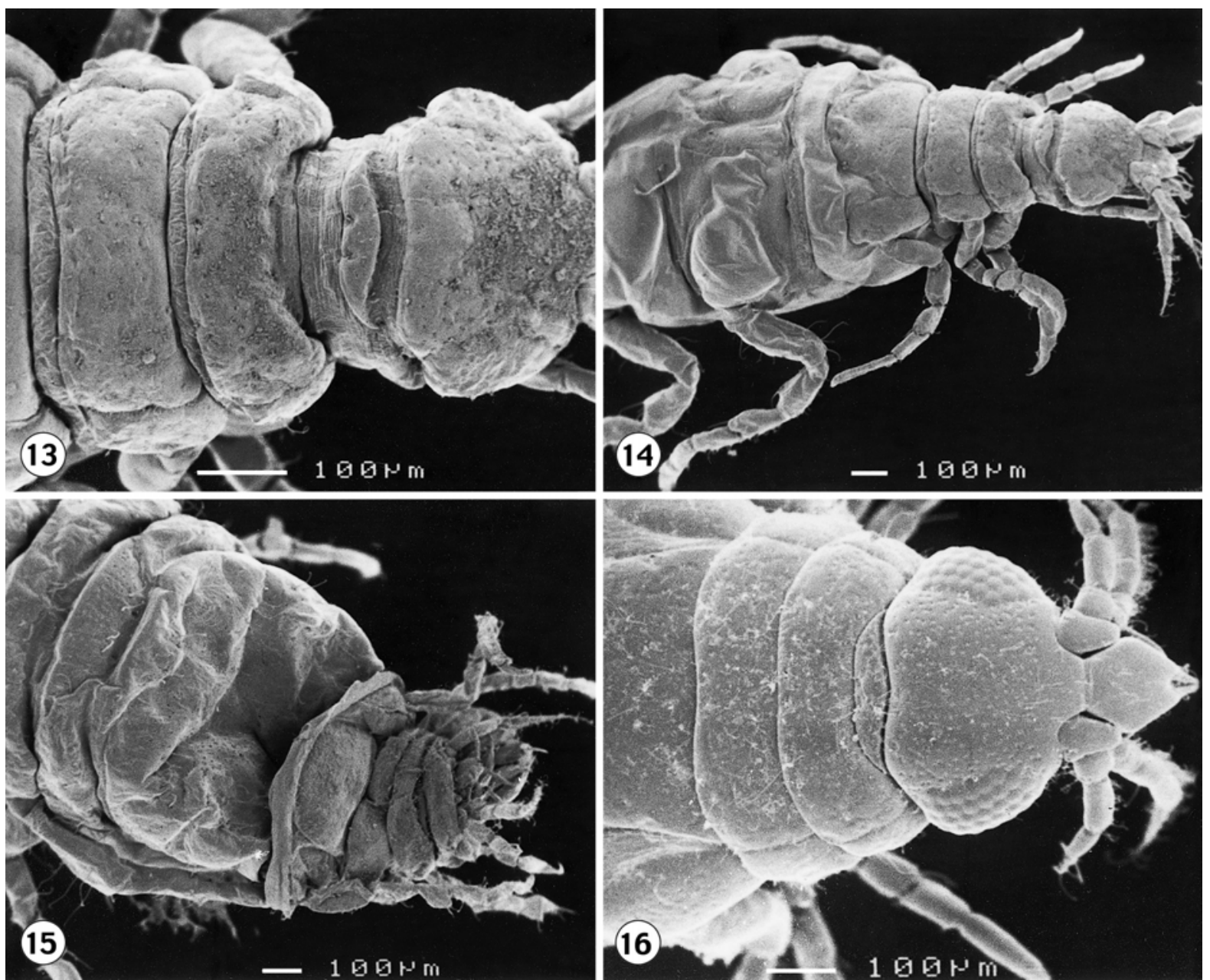

Figs. 13-16. Scanning electron micrographs of different life-cycle stages of Gnathia africana Barnard, 1914. Fig. 13. Dorsal view of cephalosome and pereonites 1-3 of male larva. Fig. 14. Male larva after completion of posterior moult. Fig. 15. Male in the process of anterior moult. Fig. 16. Broadened first 3 pereonites of a female larva.

cycle of the male. Because of the complexity of this moult, defects appeared to occur resulting in deformation of the cephalosome. All sixteen P3 male larvae collected from fish hosts completed their moult successfully, but two of the P3 larvae collected from the sponges were not able to complete the anterior moult. In the laboratory, these deformed males stayed alive for a week and two weeks respectively, but it is assumed that they would not be able to survive long in nature. The total time of the moulting process varied from 13 to 29 hours with a mean of 20 hours. Approximately four days after moulting, the cuticle of the male exoskeleton hardened and the distinct pigmentation of $G$. africana males could be observed (Fig. 4). When these males were placed with females, they were able to fertilize their eggs, thus being sexually mature. The average length of the male life cycle (from Z1 to sexually mature male) at a temperature range of $20-25^{\circ} \mathrm{C}$ was 36 days.
Female. The ovaries could be seen developing as two strings filled with immature eggs in the dorsal pereon of the female larvae five days post feeding. Due to the transparency of the larvae, the development of the eggs in the ovaries could be followed easily. The ovaries increased in size, and at nine days post feeding the eggs filled almost half (Fig. 5) and at 11 days post feeding almost three-quarters of the pereon. At day 13 post feeding, the eggs filled the whole dorsal area of the pereon (Fig. 6) and the female larva was ready to moult into an adult. At this stage the difference between the first three pereonites of the male and female larvae could be observed. Those of the female larvae (Fig. 16) were broader and stouter compared with the elongated ones of the male larvae (Fig. 13). The moulting of the female larva into an adult female took place at 16 to 17 days after feeding, and it followed the same pattern as that of the male, a posterior moult followed a few hours later by an anterior moult. Although the cephalosome of 


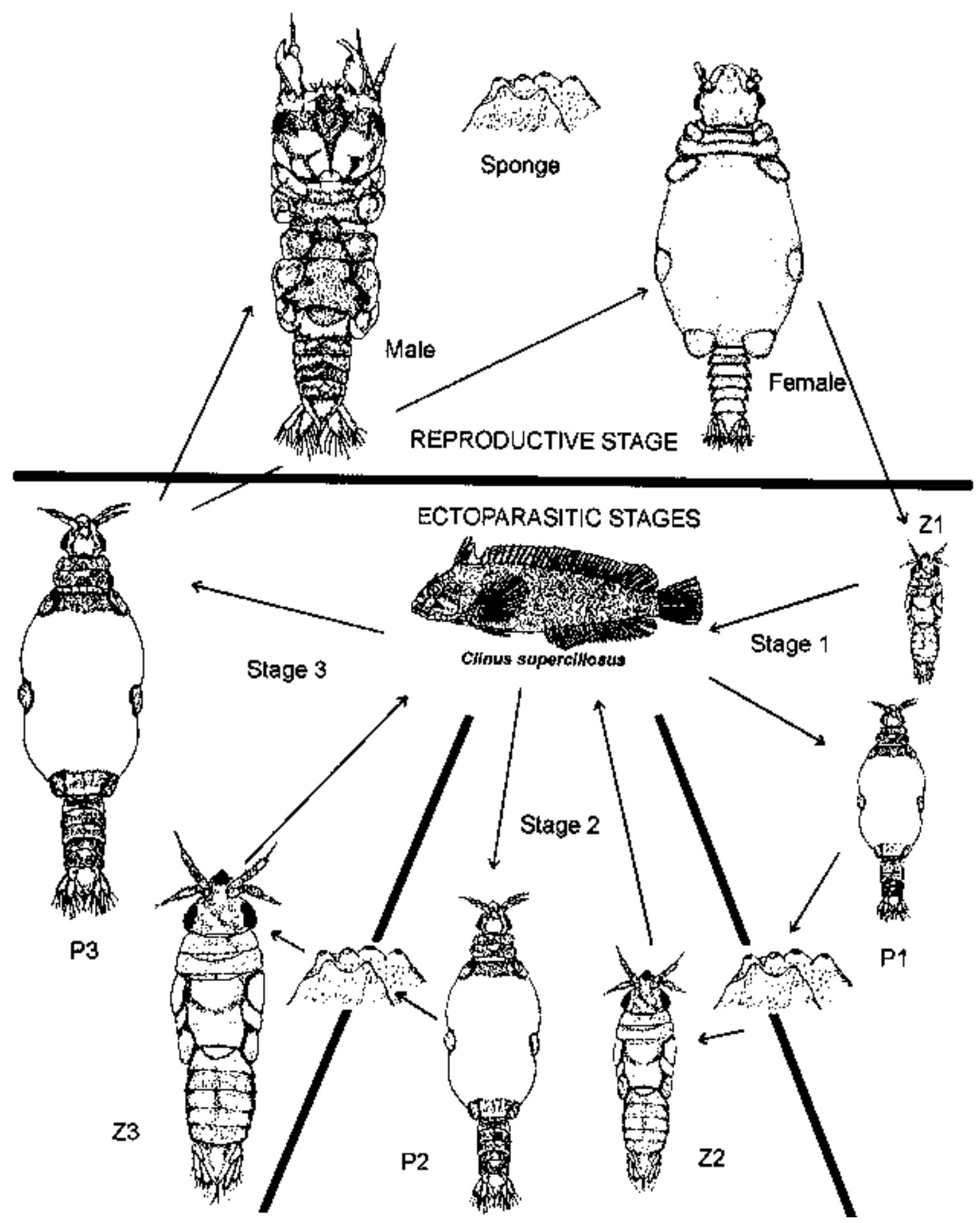

Fig. 17. Schematic representation of the life cycle of Gnathia africana Barnard, 1914. Male, praniza (P) and zuphea (Z) larvae redrawn from Smit et al. (1999), female redrawn from Smit et al. (2002), Clinus superciliosus (Linnaeus, 1758) redrawn from Penrith (1969). Not drawn to scale. 
the adult female is also totally different to that of the larvae, the moulting process was not as complex as that of the males. One of sixteen female larvae could not complete the anterior moult and died five days later. The total time of the moulting process varied from 8 to 52 hours with an average of 22 hours. On completion of the moult, the eggs were still in the dorsal ovaries of the female (Fig. 7). At this stage, internal fertilisation of the eggs by the male took place. After fertilisation at 19 days post feeding, the eggs were transferred into the ventral marsupium. The anterior hindgut with the last of the blood meal was then visible dorsally (Fig. 8). Two females were kept separately from males. In both cases the unfertilized eggs were also transferred into the ventral marsupium. The eggs could be seen degenerating after a few days and the females died 10 and 15 days later, respectively. In the remaining females, the fertilized eggs were round (Fig. 9) and no longer oval (Fig. 7) as they were prior to fertilisation. Seven days after fertilisation (19 days post feeding) cell division took place and the eggs consisted of numerous cells (Fig. 10). At 15 days after fertilisation (34 days post feeding), eyespots, as well as the cephalosome of the embryos were visible (Fig. 11). The formation of the pereon and pleon (Fig. 11) was completed by day 17 after fertilisation (36 days post feeding) and the embryos then contained yolk in their anterior hindguts as a nutrition source during their last development stages. No more yolk was visible in the embryos' anterior hindgut at 21 days after fertilisation and the distinct $G$. africana larva pigmentation was also visible (40 days post feeding) (Fig. 12). Development was concluded and the embryos were ready to leave the female as zuphea 1 larvae. During the release of the larvae, most left the female through the opening of the oostegites. However, on two occasions at the end of the releasing process, some larvae left the female through the opening between the pylopods. The trigger for release is unknown, but once the process started, it took only between 10 and 45 minutes for all the larvae to be set free. An average of 52 larvae (range of 32 to 68) was released from a single female. Upon release, the zuphea 1 larvae immediately searched for a suitable fish host on which they subsequently fed, completing the life cycle.

\section{DISCUSSION}

Feeding. It is assumed that the feeding behaviour of the zuphea larvae during the feeding experiments is similar to that found under natural conditions, since one of the natural fish hosts (Clinus superciliosus) of Gnathia africana was used. The preferred attachment position in the laboratory did, however, vary from the information obtained from wild populations. During field observations, most larvae were found attached to the pectoral and anal fins, followed in preference by the caudal, dorsal and pelvic fins, with only a small percentage of the parasites being attached to the body surface. The laboratory experiments suggested that the body of the fish is preferred, followed by the dorsal fin, pectoral fin and anal fin, with only a few attaching to the caudal and pelvic fins. These differences may be a sampling artefact. In order to experimentally infect the fish the larvae were introduced into the fish bucket from the top. Thus, larvae would swim down towards the fish and immediately attach to the first area of the fish they came into contact with. This would explain their preference for the body and dorsal fin in the laboratory. In the case of natural populations, the larvae would likely attack the fish from the bottom of the pool, thus first coming into contact with the anal, pectoral and pelvic fins of the host. This implies that the larvae probably do not have a preferred site of attachment, but rather attach to the first part of the host's body that they come in contact with. The success of their attachment is illustrated by the fact that only 5 out of the 60 larvae used in the laboratory experiments needed a second attempt to attach successfully.

Life cycle. The data compiled from this laboratory investigation indicated that the life cycle of G. africana could be summarised as follows (see Fig. 17): At a temperature range of $20-25^{\circ} \mathrm{C}$ the eggs developed after 21 days inside the female into stage 1 zuphea larvae. Immediately after leaving the maternal marsupium these larvae searched for a suitable residential tidal pool fish host such as the super klipfish Clinus superciliosus. At this stage all the larvae were almost the same size. Most of the zuphea 1 attached to the fins of the host fish where they fed on blood or lymph fluid for a period of about two hours. While feeding, the elastic part of the larva's body between pereonites 3 to 5 extended by 0.5 $\mathrm{mm}$ and this marked the transition into the praniza 1 phase. After feeding, these praniza larvae detached from their fish hosts and sought protection in sponges and tunicates, where the praniza larvae survived on the ingested blood and moulted into stage 2 zuphea larvae after eight days. Two days after moulting, the zuphea 2 larvae fed again on a fish host for between two to three hours and left the fish host as praniza 2 larvae. After a period of 10 days, they moulted into zuphea 3 larvae that fed again for three to 23 hours and subsequently became praniza 3 larvae. Male larvae moulted into adult males 10 days post feeding. Female larvae filled with eggs, moulted at 17 days into adult females. Fertilisation of the eggs by the male took place within 24 hours of completion of the female moult. The development of the embryos and subsequent release of the young larvae completed the cycle. This entire cycle took approximately 62 days.

It appears that the life cycle of $G$. africana does not follow a seasonal pattern, but instead takes place continuously throughout the year. This differs from the life cycle of Paragnathia formica, which follows a yearly cycle as well as that of Caecognathia calva, 
which has a cycle of two years, but similar to that of Elaphognathia cornigera, which appeared to have three to four generations of females per year. Tanaka and Aoki (2000) attributed the shorter life cycle of $E$. cornigera in comparison to that of $P$. formica and $C$. calva to the warmer water temperature of Japan. It is interesting to note that the water temperatures in the distribution area of $G$. africana range from as low as $9^{\circ} \mathrm{C}$ on the west coast of South Africa to $26^{\circ} \mathrm{C}$ on the south coast. Further experiments whereby gnathiids are reared at different temperatures are needed to establish the role of temperature in the life-cycle length of $G$. africana.

During the collection of specimens from sponges, no females were found. The absence of females in sponges and tunicates may be because these habitats are not the resting-place of the females. Barnard (1914a, b) was also not able to find females in sponges, but did collect them from tubes of serpulid worms. It is also interesting that no female larvae were found amongst the P3 larvae collected from sponges. Since no males and females were collected together it is difficult to comment on the possibility of the males of this species living in a monogamous relationships with a single female instead of forming a "harem" as described for Paragnathia formica and Caecognathia calva. However, if the male/female ratio found under laboratory conditions reflects the situation in natural populations, it suggests that $G$. africana males only live with one female at a time.
This study also shows that the males and females of $G$. africana do not follow asynchronous life cycles as documented for Paragnathia formica (see Upton 1987a, b). The males of $G$. africana are able to reach sexual maturity fast enough for the males and females of the same generation to mate. Whether the males of $G$. africana are able to survive long enough to mate and guard consecutive females, however, is not known.

Although the life cycle of $G$. africana follows the same basic pattern as described for the other five gnathiid species, it does differ in some aspects. The zuphea 1 larvae of G. africana immediately start to feed and do not need to moult after they have been released, as described for $G$. piscivora by Paperna and Por (1977). The P3 larvae of $G$. africana moult directly into adult males and do not go through an immature phase as described by Wägele $(1987,1988)$ for Caecognathia calva.

Although this study on the life cycle of $G$. africana is one of the most comprehensive so far, questions regarding the determination of the sex in larvae (is the sex determined in the zuphea 1 larvae or only in the P3 larval stage?), the effect of temperature on the life span, and the trigger for the release of the zuphea 1 larvae by the females, still remain unanswered.

Acknowledgement. This study was funded by the marine resource program of the National Research Foundation (NRF) of South Africa.

\section{REFERENCES}

AMANIEU M. 1963: Evolution des populations de Paragnathia formica (Hesse) au cours d'un cycle annuel. Bull. Inst. Océanogr. (Monaco) 60: 1-12.

BARNARD K.H. 1914a: Contributions to the crustacean fauna of South Africa. 1. Additions to the marine Isopoda. Ann. S. Afr. Mus. 10: 197-230.

BARNARD K.H. 1914b: Contributions to the crustacean fauna of South Africa. 3. Additions to the marine Isopoda, with notes on some previously incompletely known species. Ann. S. Afr. Mus. 10: 325a-358a, 359-442.

DAVIES A.J., SMIT N.J. 2001: The life cycle of Haemogregarina bigemina (Adeleina: Haemogregarinidae) in South African hosts. Folia Parasitol. 48: 169-177.

KLITGAARD A.B. 1991: Gnathia abyssorum (G.O. Sars, 1872) (Crustacea, Isopoda) associated with sponges. Sarsia 76: 33-39.

KLITGAARD A.B. 1997: The distribution and habitats in the North Atlantic of two gnathiid species (Crustacea, Isopoda) and their reproductive biology in the Denmark Strait and north of Iceland. Bioscience 47: 1-32.

MONOD T. 1926: Les Gnathiidae. Essai monographique (Morphologie, Biologie, Systématique). Mem. Soc. Sci. Nat. Maroc 13: 1-668

MOUCHET S. 1928: Note sur le cycle évolutif des Gnathiidae. Bull. Soc. Zool. Fr. 53: 392-400.
PAPERNA I., POR F.D. 1977: Preliminary data on the Gnathiidae (Isopoda) of the Northern Red Sea, the Bitter Lakes and the Eastern Mediterranean and the biology of Gnathia piscivora n. sp. Rapp. P.-v. Réun. Comm. Int. Explor. Sci. Mer Méditerr. 24: 195-197.

PENRITH M. 1969: The systematics of the fishes of the family Clinidae in South Africa. Ann. S. Afr. Mus. 55: 1121.

SMIT N.J., DAVIES A.J. 1999: New host records for Haemogregarina bigemina from the coast of southern Africa. J. Mar. Biol. Assoc. U.K. 79: 933-935.

SMIT N.J., VAN AS J.G., BASSON L. 1999: A redescription of the adult male and praniza of Gnathia africana Barnard, 1914 (Crustacea, Isopoda, Gnathiidae) from southern Africa. Folia Parasitol. 46: 229-240.

SMIT N.J., VAN AS J.G., BASSON L. 2002: Redescription of the female of Gnathia africana Barnard, 1914 (Crustacea: Isopoda: Gnathiidae) from southern Africa. Folia Parasitol. 49: 67-72.

SMITH G. 1904: Metamorphosis and life-history of Gnathia maxillaris. Mitt. Zool. Neapel 16: 469-474.

STOLL C. 1962: Cycle évolutif de Paragnathia formica (Hesse) (Isopoda: Gnathiidae). Cah. Biol. Mar. 3: 401416. 
STOLL C. 1963: La mue en deux temps chez Paragnathia formica (Hesse) (Isopoda, Gnathiidae). Zool. Exp. Gen. 104: 1-23.

TANAKA K., AOKI M. 1998: Crustacean infauna of the demosponge Halichondria okadai (Kadota) with reference to the life cycle of Gnathia sp. (Isopoda: Gnathiidea). In: Y. Watanabe and N. Fusetani (Eds.), Sponge Science: Multidisciplinary Perspectives. Springer-Verlag, Tokyo, pp. 259-267.

TANAKA K., AOKI M. 1999: Spatial distribution patterns of the sponge dwelling gnathiid isopod Elaphognathia cornigera (Nunomura) on an intertidal rocky shore of the Izu Peninsula, southern Japan. Crustacean Res. 28: 160 167.

TANAKA K., AOKI M. 2000: Seasonal traits of reproduction in gnathiid isopod Elaphognathia cornigera (Nunomura, 1992). Zool. Sci. 17: 467-475.

Received 1 May 2002
UPTON N.P.D. 1987a: Asynchronous male and female life cycles in the sexually dimorphic, harem-forming isopod Paragnathia formica (Crustacea: Isopoda). J. Zool. Lond. 212: 677-690.

UPTON N.P.D. 1987b: Gregarious larval settlement within a restricted intertidal zone and sex differences in subsequent mortality in the polygynous saltmarsh isopod Paragnathia formica (Crustacea: Isopoda). J. Mar. Biol. Assoc. U.K. 67: 663-678.

WÄGELE J.W. 1987: Description of the postembryonal stages of the Antarctic fish parasite Gnathia calva Vanhöffen (Crustacea: Isopoda) and synonymy with Heterognathia Amar \& Roman. Polar Biol. 7: 77-92.

WÄGELE J.W. 1988: Aspects of the life cycle of the Antarctic fish parasite Gnathia calva Vanhöffen (Crustacea: Isopoda). Polar Biol. 8: 287-291.

Accepted 17 January 2003 